\title{
COMPLETAMOS UM ANO
}

unto ao Mestrado Profissional em Gestão da Economia Criativa da ESPM-Rio de Janeiro, nasceu a Revista Diálogo com a Economia Criativa. Com este terceiro número, nossa revista do programa de mestrado completa um ano de existência. Ao planejarmos esta edição, nosso principal objetivo foi abrir um espaço para que pesquisadores pudessem aumentar o fluxo de diálogos em prol da geração de ideias criativas.

O leitor poderá observar nesta obra, assim como nas duas anteriores, que o espaço aberto está sendo preenchido com a expertise de pesquisadores de diversas áreas, mas sempre apoiada no campo da criatividade.

Os temas apresentados neste número são uma consolidação de reflexões interdisciplinares relacionadas à Economia Criativa. Sob a ótica do mercado, os artigos podem oferecer ao leitor respostas inovadoras, sustentáveis e eficazes às adversidades enfrentadas na atual conjuntura macroeconômica.

Tivemos a honra de receber neste número uma entrevista exclusiva do Professor Manuel Castells, uma das maiores referências no debate sobre as mudanças provocadas pelas novas tecnologias. Em sua entrevista, o professor afirma que a Economia Criativa, por estar orientada para o consumo de bens e serviços, deve ser organizada como uma indústria. Seus agentes precisam se preocupar com capital de risco, marketing e estratégia. Castells foi professor da Universidade de Paris e é professor emérito na Califórnia University, em Berkeley, onde lecionou por 24 anos. Atualmente, é professor de comunicação na University of Southern Califórnia, em Los Angeles. A entrevista foi conduzida pela jornalista e pesquisadora Sandra Mesquita Sanches e pelo pesquisador João Luiz de Figueiredo.

O estudo sobre programa de televisão MasterChef Brasil, apresentado por Adelaide Rocha de la Torre Chao e João Luis de Araújo, procura avaliar como a memória e a identidade estão relacionadas à comida enquanto fenômeno comunicacional, como a culinária se estabelece no imaginário coletivo e afetivo através de uma narrativa que recorre às situações do passado.

No texto: "A cidade do Rio de Janeiro, a praia e o biquíni: uma receita de moda", a pesquisadora Adriana Sampaio Leite tem como proposta central demostrar como a moda praia tornou-se um componente genuíno e valorizado da economia criativa brasileira e produto de uma determinada cultura.

Os pesquisadores Geovane Ferreira Gomes, Alessandra Baiocchi Antunes Corrêa e Luís Alexandre Grubits de Paula Pessôa trazem o trabalho "Consumo de música: um estudo de marketing geracional". Trata-se de um estudo que visa entender o consumo dos diversos formatos de distribuição de música, tais como CDs, DVDs, programas de streaming, entre outros, por consumidores das gerações $X$ e $Y$.

Sílvia Helena de C. Schnaider e Sydney Fernandes de Freitas apresentam dados sobre a criação de mais de setecentos cursos Superiores de Design no Brasil desde a década de 60. Os dados desta pesquisa documental foram retirados do portal do MEC-Ministério da Educação. 
O trabalho apresentado por Verônica Daminelli Fernandes buscou analisar como a produção literária se insere no contexto da Economia Criativa como espaço de luta e denúncia sociais. A autora usou o livro "Crônicas do Mal de Amor", da italiana Elena Ferrante, para este estudo.

Podemos dizer que a cada trabalho publicado promovemos, renovamos e multiplicamos uma matéria prima inesgotável composta por cultura, criatividade e conhecimento.

Aos pesquisadores, colaboradores e pareceristas que contribuíram para a construção desta obra, o meu cordial agradecimento.

Uma excelente leitura a todos!

Profa. Dra. Veranise Dubeux

Editora da Revista Diálogo com a Economia Criativa

Professora Doutora do Mestrado Profissional em Gestão da Economia Criativa 